\title{
Ankle joint traumas rehabilitation methods
}

\author{
Vitaly Skitnevsky ${ }^{1}$, Elena Grigoryeva ${ }^{1}$, Ivan Sedov ${ }^{1}$, Yulia Krasilnikova $^{1 *}$, Valentina Balashova ${ }^{2}$ \\ ${ }^{1}$ Kozma Minin Nizhny Novgorod State Pedagogical University, 603005, Nizhny Novgorod, Russia \\ ${ }^{2}$ Institute of Physical Education and Sports of Togliatti State University, 445020, Togliatti, Russia
}

\begin{abstract}
Traumas of ankle joint are the most common. Ankle injuries account for 20 to 30 $\%$ of all traumas of the human locomotor system. During the life process, the ankle is subjected to sufficiently heavy loads, therefore joint injuries often occur. Impact injuries, strains and ruptures of ligaments, dislocations, and fractures may be caused by any careless movement. Sedentary lifestyle causes atrophy of muscles and ligaments, their endurance decreases. That is why any improper movement may lead to an ankle trauma. The relevance of this article is determined by the search of ankle joint traumas rehabilitation methods, which in the future may be a solution to the problem of children 12 to 14 years of age recovery. The authors of the article have reviewed rehabilitation methods of ankle injuries and have analyzed the influence of physical activity on the recovery process. The goal of the research is to determine the effect of rehabilitation means aimed at recovery of the ankle joint motor function. We raised a question: how the use of physical rehabilitation means may favor the improvement of functional activity of the ankle joint.
\end{abstract}

\section{Introduction}

The following are the most common causes of ankle injuries: improper landing when jumping off high objects, landing on uneven surfaces, falling. One more factor of endurance decrease of ankle ligaments and synovial capsule of the ankle joint is age. On the other hand, high level of physical activity also contributes to the risk of ankle joint injuries. Traumas of ankle ligaments are the most common injuries among athletes [2, 3, 4].

Physical rehabilitation is the leading method of the ankle joint recovery. Early and comprehensive rehabilitation is the most advanced method of the injured ankle joint motor functions recovery. Comprehensive rehabilitation widely uses methods of physical rehabilitation - therapeutic physical exercises, hydrotherapy, massage, physiotherapeutic procedures [5, 7].

Based on the outlined goal, the following tasks were identified:

1. Study the problem of the research, based on literature sources;

2. Develop exercises for rehabilitation of ankle joint traumas;

3. Validate the efficiency of the developed rehabilitation method.

\section{Materials and methods}

The experiment in development of a set of exercises of adaptive physical training aimed at rehabilitation of ankle joint traumas was held at the State Municipal Institution of Nizhniy Novgorod Region "Exercise Therapy Centre" (8A Krasnykh Partizan Str., Nizhniy Novgorod, Russia).

10 children aged 12 to 14 years took part in the experiment. All children had injuries of ankle joints and at the time were in the third period of recovery (see Chart 2). To validate the experiment, two groups were formed: experimental (10 people) and reference (10 people). The development of the set of exercises aimed at rehabilitation of ankle joint traumas was carried out throughout the whole period of exercising. Later on, a second round of research was held in the same conditions to assess the results.

During the first stage of the research it was found out, that physical rehabilitation is a logical continuation of any kind of treatment: surgical, pharmaceutical, physiotherapeutic, and is aimed at recovery of qualitative capabilities of the ankle joint.

The rehabilitation program is a certain sequence of actions. They have to be made to restore the lost motor functions. The main tool of rehabilitation is exercising. The exercises need to be selected correctly with account for the specifics of the injury, properly organized through the use of technical means, fixtures, special rehabilitation equipment, and correctly performed $[1,11,14,15]$.

\section{Results and discussion}

The following tests were performed during the experiment $[9,12,13]$ :

\footnotetext{
* Corresponding author: krasiljuliapocht@yandex.ru
} 
1. Assessment of the general physical condition of 12 to 14 years of age children with ankle injuries before and after rehabilitation;

2. Assessment of the injured joint motion range with goniometer;

3. Assessment of walking characteristics of children with an injured ankle before and after rehabilitation;

4. Bondarevsky test to assess balancing ability before and after rehabilitation.

After completion of the rehabilitation, statistically significant positive shifts occurred in functional conditions of 12 to 14 years of age children ankle joints that took part in the research (Table 1).

Table 1. Dynamics of shin circumference, goniometry, pace, step length, and walking speed of 12 to 14 years of age children during the experiment.

\begin{tabular}{|c|c|c|c|c|c|c|c|}
\hline \multirow{2}{*}{$\begin{array}{l}\text { Research } \\
\text { group }\end{array}$} & \multirow{2}{*}{$\begin{array}{c}\text { Examination } \\
\text { period }\end{array}$} & \multirow{2}{*}{$\begin{array}{c}\text { Shin } \\
\text { circumference } \\
(\mathrm{cm})\end{array}$} & \multicolumn{2}{|c|}{$\begin{array}{l}\text { Goniometry } \\
\text { (degrees) }\end{array}$} & \multirow{2}{*}{$\begin{array}{c}\text { Pace } \\
\text { (step/min) }\end{array}$} & \multirow{2}{*}{$\begin{array}{l}\text { Length of } \\
\text { step }(m)\end{array}$} & \multirow{2}{*}{$\begin{array}{c}\text { Walking } \\
\text { speed }(\mathrm{km} / \mathrm{h})\end{array}$} \\
\hline & & & bending & extending & & & \\
\hline \multirow{4}{*}{$\mathrm{n}=10$} & $\begin{array}{c}\text { Before } \\
\text { examination }\end{array}$ & $31.4 \pm 1.16$ & $35.8 \pm$ & $16.1 \pm$ & $82.3 \pm$ & $44.8 \pm$ & $3.64 \pm$ \\
\hline & $\begin{array}{c}\text { After } \\
\text { examination }\end{array}$ & $32.2 \pm 1.4$ & $41.4 \pm$ & $18.2 \pm$ & $88.6 \pm$ & $52 \pm$ & $4.46 \pm$ \\
\hline & \multirow{2}{*}{$\begin{array}{c}\text { Statistical } \\
\text { significance }\end{array}$} & 7.8 & 19.4 & 17.7 & 18.4 & 15.9 & 21.5 \\
\hline & & $\mathrm{p}<0.001$ & $\mathrm{p}<0.001$ & $\mathrm{p}<0.001$ & $\mathrm{p}<0.001$ & $\mathrm{p}<0.001$ & $\mathrm{p}<0.001$ \\
\hline
\end{tabular}

Note: statistical significance was calculated by Student's T-test.

According to the results of the research, we were able to determine shin circumference before and after the experiment in the research group. Before the experiment, the shin circumference was on average $31.5 \mathrm{~cm}$, after application of the developed method $-32.1 \mathrm{~cm}$. It indicates a change in the result by $0.6 \mathrm{~cm}$ (with p $<0.001$ ).

After application of therapeutic physical training set of exercises, the results of walking goniometry of 12 to 14 years of age children have also improved: the bending angle changed by $5.3^{\circ}$, and angle of extension changed by $2.7^{\circ}$. The bending angle was $41.9^{\circ}$, and the angle of extension was $19.3^{\circ}$ (with $\mathrm{p}<0.001$ ). At the beginning of the experiment the average bending angle of the ankle joint was $36.6^{\circ}$, and average angle of extension was $16.6^{\circ}$.

It is worth noting that functional state of the joints and main characteristics of the group walking under examination improved after the rehabilitation methods had been implemented.

The length of step of children from the experimental group has improved on average by $0.7 \mathrm{~m}$ and was equal to $52.2 \mathrm{~m}$. At the beginning of the experiment the children walked with the speed of $3.66 \mathrm{~km} / \mathrm{h}$, and at the end of the experiment the walking speed was $4.65 \mathrm{~km} / \mathrm{h}$ (with $\mathrm{p}<0.001$ ). The muscular strength of lower limbs, namely of the ankle joint, improved, and muscular tone recovered.

The rehabilitation program for ankle injuries for children of 12 to 14 years of age is intended for 30 days and includes sets of physical exercises, combined with electrophoresis, magnet therapy, and massage. Massage was performed daily.

During each session, the state of a child health was closely monitored. At significant levels of pain, the exercises were performed at slow pace, and with severe levels of pain the exercises were performed at the pace most comfortable for the child. In proportion to pain relief, the exercises were performed at a more rhythmical moderate pace: each exercise was performed 10 to 15 times; the most painful move was performed 5 to 7 times.

The movement amplitude was carefully selected not to cause pain increase. The amplitude was gradually increased, and all the movements were performed until the "pain point" was reached. All exercises were performed freely, smoothly, without any effort or abrupt movements. All of the movements were firstly performed with the healthy limb, and only then with the injured one.

During sessions the correct interchange of exercises was accounted for. If the pain levels increased during an exercise, the patient stopped the performance of this exercises and tried again after several sessions when the pain levels dropped.

A set of exercises aimed at training of muscular strength and resistance to static and dynamic loads with the use of isometric exercises and active exercises or resistance exercises (with the use of rubber band, expander), and exercises aimed at recovery of kinesthetic sense $[6,8,10]$ were used as remedial gymnastics. Such exercises were performed daily.

See Table 2 below for the list of exercises that were performed at this stage of rehabilitation.

Table 2. Examples of exercises of Set 1

\begin{tabular}{|c|c|c|c|}
\hline No & Starting position & Description & $\begin{array}{l}\text { Number of } \\
\text { repetitions }\end{array}$ \\
\hline 1 & $\begin{array}{l}\text { Lying flat on back, or } \\
\text { seating with slightly bent } \\
\text { knees }\end{array}$ & Active bending and extension of toes & $10-15$ \\
\hline 2 & $\begin{array}{l}\text { Lay one forefoot on top of } \\
\text { the other }\end{array}$ & Resistance bending and extension of the foot. & $10-15$ \\
\hline 3 & $\begin{array}{l}\text { Lying flat on back or } \\
\text { seating }\end{array}$ & $\begin{array}{l}\text { The injured leg lies on top of the healthy leg knee. The } \\
\text { healthy leg is bent in knee. Active bending and extension, }\end{array}$ & $10-12$ \\
\hline
\end{tabular}




\begin{tabular}{|c|l|l|l|}
\hline & & circular motions of the ankle joint. & \\
\hline 4 & Seating & $\begin{array}{l}\text { Pick small objects up with toes (pencil, small balls, } \\
\text { buttons) }\end{array}$ & $10-12$ pick ups \\
\hline 5 & Seating & Roll a tennis ball with tiptoes & $\begin{array}{l}10-12 \text { back and } \\
\text { forth }\end{array}$ \\
\hline 6 & Seating & $\begin{array}{l}\text { Bending, extension, adduction and abduction of the foot } \\
\text { with rubber band }\end{array}$ & $\begin{array}{l}15 \text { up and down, } \\
\text { inward and outward }\end{array}$ \\
\hline 7 & $\begin{array}{l}\text { Seating or standing and } \\
\text { holding onto wall bars }\end{array}$ & Foot roll from toe to heel and back & $12-15$ \\
\hline 8 & $\begin{array}{l}\text { Seating or standing and } \\
\text { holding onto wall bars }\end{array}$ & Half-squatting with heels down & $12-15$ \\
\hline 9 & $\begin{array}{l}\text { Standing on the 2 } \\
\text { rail of the wall bar facing } \\
\text { the wall bar }\end{array}$ & $\begin{array}{l}\text { Hands grip at the chest level. Spring-like movements } \\
\text { standing on tiptoes, the heel should go down as low as } \\
\text { possible }\end{array}$ & $12-15$ \\
\hline 10 & $\begin{array}{l}\text { Seating or standing and } \\
\text { holding onto wall bars }\end{array}$ & $\begin{array}{l}\text { Tiptoes climbing with additional spring-like squats on the } \\
\text { tiptoe of the injured leg }\end{array}$ & $15-20$ \\
\hline
\end{tabular}

In one week a second set of exercises was implemented to train balance. It included proprioceptive exercises with the use of a balancing disk (Table 2).

Table 3. Examples of exercises of Set 2

\begin{tabular}{|c|c|c|}
\hline No & Starting position & $\begin{array}{ll} & \text { Description } \\
\end{array}$ \\
\hline 1 & $\begin{array}{l}\text { Standing, feet together, arms } \\
\text { stretched to the sides, eyes closed }\end{array}$ & $\begin{array}{l}\text { Retain standing position for } 20 \text { to } 30 \text { seconds. Put arms down along the body } \\
\text { and retain this position for additional } 15 \text { to } 20 \text { seconds. }\end{array}$ \\
\hline 2 & $\begin{array}{l}\text { Standing, feet together, arms } \\
\text { stretched to the sides, eyes closed }\end{array}$ & $\begin{array}{l}\text { Rise on tiptoes and retain this position for } 10 \text { to } 15 \text { seconds. Close the eyes. } \\
\text { Stand with eyes closed for additional } 10 \text { to } 15 \text { seconds. Put arms down along } \\
\text { the body and retain this position for additional } 15 \text { to } 20 \text { seconds. }\end{array}$ \\
\hline 3 & $\begin{array}{l}\text { Standing, feet together, arms } \\
\text { stretched to the sides, eyes closed }\end{array}$ & $\begin{array}{l}\text { Rise on tiptoes, bend the head back and retain this position for } 8 \text { to } 10 \\
\text { seconds. Close the eyes and retain this position for additional } 5 \text { to } 7 \text { seconds. }\end{array}$ \\
\hline 4 & $\begin{array}{l}\text { Standing, feet together, arms } \\
\text { stretched to the sides, eyes closed }\end{array}$ & $\begin{array}{l}\text { Put the feet together, rise on tiptoes, while retaining the starting position } \\
\text { quickly bend the head back and forth. }\end{array}$ \\
\hline 5 & $\begin{array}{l}\text { Standing, feet together, arms along } \\
\text { the body. Raise the left knee to the } \\
\text { waistline; stretch the arms to the } \\
\text { sides. }\end{array}$ & $\begin{array}{l}\text { Retain the position for } 10 \text { to } 15 \text { seconds. Close the eyes. Retain this position } \\
\text { for additional } 10 \text { to } 15 \text { seconds. Switch legs and repeat the exercise. }\end{array}$ \\
\hline 6 & $\begin{array}{l}\text { Standing, feet in one line (right foot } \\
\text { in front of the left foot, heel of the } \\
\text { right foot touching the toes of the } \\
\text { left foot), arms stretched to the } \\
\text { sides }\end{array}$ & $\begin{array}{l}\text { Retain the position for } 20 \text { to } 30 \text { seconds. Put arms down along the body, and } \\
\text { retain this position for additional } 20 \text { to } 30 \text { seconds. Close the eyes and retain } \\
\text { the position for additional } 15 \text { to } 20 \text { seconds. }\end{array}$ \\
\hline 7 & $\begin{array}{l}\text { Standing, feet in one line (right foot } \\
\text { in front of the left foot, heel of the } \\
\text { right foot touching the toes of the } \\
\text { left foot), hands on hips }\end{array}$ & $\begin{array}{l}\text { Lean } 6 \text { to } 8 \text { times to left and right, keeping the balance. Repeat the exercise } \\
\text { with eyes closed. }\end{array}$ \\
\hline 8 & $\begin{array}{l}\text { Standing, arms stretched along the } \\
\text { body }\end{array}$ & $\begin{array}{l}\text { Slowly raise the hands overhead and spread them, at the same time pull the } \\
\text { right stretched leg back. Try to lower the body until parallel to the floor. } \\
\text { Retain this position for } 20 \text { to } 30 \text { seconds. Switch legs and repeat the exercise } \\
\text { with the eyes closed. }\end{array}$ \\
\hline
\end{tabular}
home.

The set was performed by the children 2 times per day for 30 minutes: first time at the gym, second time - at

\section{Conclusions}

The rehabilitation program is intended for 30 days and includes sets of physical exercises combined with electrophoresis, magnet therapy and massage. A set of exercises aimed at training of muscular strength and resistance to static and dynamic loads with the use of isometric exercises and active exercises or resistance exercises (with the use of rubber band, expander), and exercises aimed at recovery of kinesthetic sense were used as remedial gymnastics. A set of exercises aimed at training of balance, which included proprioceptive exercises with the use of a balancing disk was also implemented. During the course of solving the third task, the efficiency of the developed rehabilitation method was assessed by means of testing.

The research has shown that the rehabilitation of the ankle joint is one of the most important factors of restoring motor activity by way of using the means and methods of physical training with adequate loads, combined with other means of comprehensive rehabilitation methods aimed at improvement of the recovery process efficiency after ankle joint injuries. 


\section{References}

1. G.A. Butko, T.A. Katelson, S.P. Oltu, Vestnik of Minin University, 4(29)-7, 5, (2019)

2. N.S. Gusakova, Problems of development of the social sector in Russia and abroad. Collection of research papers adapted from the It International Research-to-Practice Conference $(476$ - 485, 2017)

3. Z.I. Kiseleva, M.R. Valetov, V.V. Shlyapnikova, Azimuth of scientific research: pedagogy and psychology, 2(27)-8, 1-3 (2019)

4. O.V. Limarenko, Health for everyone, 2, 47-51 (2012)

5. O.B. Nagornaya, Physical education and Sports - basics of the healthy nation. Collection of articles of the III ${ }^{\text {rd }}$ International Research-to-Practice Conference $(206$ - 213, 2016)

6. N.A. Nalobina, T.A. Nikitenko, Recovery Medicine Herald, 3(67), 55-59 (2015)

7. A.S. Kuznetsov, Z.M. Kuznetsova, Russian Journal of Physical Education and Sport, 14(4), 5-7 (2019). DOI: 10.14526/2070-4798-2019-14-4-5-7

8. T.O. Savinykh, Candidate's thesis (M, 2015)

9. N.Y. Tarabrina, Adaptive physical training and therapeutic-resort rehabilitation: innovative technology and development priorities. Collection of scientific papers based on materials of all-Russian Research-to-Practice Conference $(227-233$, 2017)

10. P.N. Telitsyn, N.G. Zhila, Far Eastern Medical Magazine, 3, 31-35 (2016)

11. Z.I. Tyumaseva, I.L. Orekhova, Vestnik of Minin University, 3(28)-7, 5 (2019)

12. Z.K. Kholodov, V.S. Kuznetsov, Theory and methods of physical education and sports: study guide (Akademiya, M., 2000)

13. O.E. Chaikovskaya, Almanac of world science, 12-2(15), 47-50 (2016)

14. E.V. Bystritskaya, V.L. Skitnevskiy, Y.S. Krasilnikova, E.L. Grigoriyeva, I.A. Sedov, V.F. Balashova, C.N. Germanov, Magazine of Environmental Treatment Techniques, 2(8), 674-678 (2020)

15. V.L. Skitnevskiy, A.V. Reva, J.S. Novozhilova, I.A. Sedov, O.V. Sesorova, A.A. Zelenova, Modern magazine of language teaching methods, 5(8) 355-366 (2018) 